\title{
Accountability of Business Actors against Expired Imported Products
}

\author{
Khosyi Lathifah $^{1 *}$, Siti Mahmudah ${ }^{1}$, Hendro Saptono ${ }^{1}$ \\ $\left\{\right.$ khosyil11@gmail.com ${ }^{* 1}, \underline{\text { sitimahmudah@live.undip.ac.id }}$, hendrosaptono@live.undip.ac.id $\left.{ }^{3}\right\}$
}

Fakultas Hukum, Universitas Diponegoro, Jl. Prof. H. Soedarto, S.H., Semarang, Indonesia $50275^{1}$

\begin{abstract}
Expired imported food found in the community that can endanger human health. Imported foods are regulated under the Food Law and involve distributors, and this research was conducted to dive deep into expired imported food regulations and the responsibilities of distributors as business actors. The research method uses normative juridical methods with secondary data obtained through a literature study on legal materials which include primary, secondary and tertiary data with descriptive-analytical as specifications. The results showed that expired imported food was banned and regulated in the Food Law. Meanwhile, the distributor is responsible for expired imported food. This study concludes that imported food that has expired is regulated in the Food Law related to the permitted and prohibited import food requirements. Expiration is prohibited because it is considered as tainted food. In addition, the Food Law regulates the responsibility of contributors as business operators that circulate expired imported food.
\end{abstract}

Keywords: responsibility, imported food, expired

\section{Introduction}

Formally, the definition of food is on Article 1 Number (1) of the Food Law, stating that food is anything derived from biological sources and water, whether processed or not processed, which is intended as food or drink for human consumption, including food additives, food raw materials and other materials used in the preparation, processing and/or manufacturing of food or beverages.[1]

Quality, nutritious, and balanced food are major prerequisite for the interests of the people's health, prosperity, and welfare. Meeting the needs of food and nutrition is an important factor to develop quality Indonesian people in order to improve the nation's competitiveness. These things influence the holding of protection for food, and therefore the legal rules governing food as a part of efforts to protect food.

The protection of food in the form of written regulations, governed by Law No. 18 of 2012 concerning Food. One of the regulation is regarding food imports. Food imports are regulated because countries in the world have not been able to produce all the goods and their own needs because of the limited resources available in these countries, so they must receive assistance from other countries. This process then becomes an activity called trade between countries, or export-import activities. However, in the current era of globalization and technological development, many Indonesian industries are competing to produce goods including food and beverages which continue to grow rapidly. Therefore, the community must 
be more careful in choosing food and beverage products that are circulating and marketed in Indonesia. In buying and selling activities, especially in the field of food and beverages (food), there are many problems that arise. [2] The tight competition can change behavior towards unfair competition because business actors have conflicting interests between themselves. This unhealthy competition can in turn harm consumers. Some people deliberately to obtain greater profits to perform various actions in the cheat category. [3]

One that happens a lot and endangers the community is expired food products. Expiration is a condition in which a product has been said to be unfeasible because it is past the specified time on its packaging. Expired food is no longer suitable for consumption, and therefore, the government must always supervise the food sold at supermarkets and small shops that have passed the expiration period. Thus, the responsibility of business actors to consumers must be implemented within the framework of economic life in social life in Indonesia and the need for supervision from the authorized institutions. Therefore, the authors are interested in discussing and making a thesis with the title "Accountability of Business Actors against Expired Imported Products under Law No. 18 of 2012 Regarding Food."

Based on the description of the background above, the writer will examine several issues, namely:

1. How to regulate expired imported food based on Law no. 18 of 2012 ?

2. How is the responsibility of business actors for distributing imported products that have expired?

\section{Method}

The method of approach used in this study is a normative juridical approach method, namely legal research conducted by examining library materials or secondary data as a basic material to be investigated by conducting a search of the regulations and literature relating to the problem under study.[4]

This normative juridical approach will begin by reviewing the laws and regulations regarding food, which will then be analyzed the responsibilities of business operators for expired imported food which are expected to provide a real and systematic picture and answers to these problems.

\subsection{Research Specification}

The research specification that will be used is analytical descriptive, which is a study that describes in full the applicable laws and regulations and is then associated with legal theories and practices of implementing positive law concerning the problems, then analyzes the data obtained to then draw conclusions from that research.[4]

\subsection{Method of collecting data}

The writing of this law uses a normative juridical approach. Secondary data is data whose source is based on library research. Secondary data can come from primary legal materials, secondary legal materials and tertiary legal materials as well as prior research relating to the object of study in research. The details are as follows: 


\subsubsection{The primary legal materials used in this study consisted of:}

1) Civil Code;

2) Law No. 18 of 2012 concerning Food

3) Law No. 7 of 2014 concerning Trade

4) Government Regulation No. 69 of 1999 concerning Food Labels and Advertisements.

5) Government Regulation No. 28 of 2004 concerning Food Safety, Quality and Nutrition

6) Regulation of the Minister of Trade of the Republic of Indonesia No. 77 of 2018 concerning Integrated Business Licensing Services

7) Regulation of the Minister of Trade of the Republic of Indonesia No. 13/MDAG/PER/3/2012

8) Regulation of the Minister of Finance No. 161/Pmk.04/2007 concerning Supervision of Import or Export of Prohibited and/or Restricted Goods

9) Regulation of the Minister of Health No. 180/MEN.KES/PER/IV/1985

10) Indonesian Minister of Trade Regulation No. 11/M-DAG/PER/3/2006 concerning Provisions and Procedures for Issuance of Registration Certificate of Agents or Distributors of Goods and/or Services

11) Minister of Trade Regulation No. 48/M-Dag/Per/7/2015 2015 concerning General Provisions in Import

12) Decree of the Head of the Republic of Indonesia Drug and Food Supervisory Agency No: HK.00.05.5.1639 concerning Guidelines for Good Food Production Methods for Home Industries (CPPB-IRT)

\subsubsection{Secondary legal materials used in writing this law include:}

1) Books on Export-Import Transactions, Business Law, Food, Nutrition, and Agriculture, and Research Methodology;

2) Papers and articles;

3) Journal;

4) Other reference material.

\subsubsection{Tertiary legal material consisting of:}

1) Legal Dictionary;

2) Large Indonesian Dictionary;

3) Other reference materials.

\section{Results and Discussion}

\subsection{Expired Food Import Regulations According to Law No. 18 of 2012 concerning Food}

Article 1 Number (1) concerning Food, hereinafter referred to as the Food Law, gives the meaning of food is anything that comes from biological sources and water, whether processed or not processed, which is intended as food or drink for human consumption, including food additives, food raw materials and other materials used in the preparation, processing and/or manufacturing of food or beverages.[1] 


\subsubsection{Food Import}

According to Law No. 18 of 2012 on food, food import is the activity of entering food into the customs territory of the Republic of Indonesia which includes land, water, airspace, certain places in the Exclusive Economic Zone, and continental shelf. Based on this understanding, Imports can be known as buying and selling activities by entering goods from abroad into the country with the aim of meeting domestic needs.

\subsection{Food Import Subjects}

People who import food are called food importers. Importers are individuals or institutions or business entities, both in the form of legal entities and not legal entities, who carry out imports. [5] Food businesses according to Law No. 18 of 2012 on Food is Every Person engaged in one or more food agribusiness subsystems, namely providers of input production, production processes, processing, marketing, trade, and support.

a) Food Import Subjects Requirements

Food imports are trading activities carried out on the basis of an agreement between the buyer and seller. Therefore, food import is a form of agreement, especially an agreement on buying and selling. The agreement contains terms and conditions cited from Article 1320 of the Civil Code. The first and second conditions are called subjective conditions because both conditions must be met by legal subjects.[6] The subjective conditions are:

a. Agree Those Who Bind Themselves

b. Ability to Make an Agreement

Non-fulfillment of subjective conditions results in an agreement being canceled. The point is that the agreement becomes nullified if there is an application for cancellation. Therefore, subjective conditions must be fulfilled by the parties entering into the agreement.

To become an Importer, there are subjective conditions that must be fulfilled by food importers. Subjective conditions is written both on Civil Code and on Article 8 of the Regulation of the Minister of Trade of the Republic of Indonesia No. 11/M-DAG/PER/3/2006, which are the requirements that must be fulfilled by distributors as food import businesses, namely:[7]

a. Application for registration as a distributor or sole distributor of goods and/or overseas production services is submitted to the Director of Business Development and Company Registration by enclosing following documents:

b. Agreement that has been legalized by the Public Notary and a certificate from the Indonesian Trade Attache or the Official of the Republic of Indonesia Representative Office in the principal country, by showing the original;

c. Copy of authority of the producer's principal only If the agreement is made by the supplier's principal,

d. Copy of Trading Business License (SIUP);

e. Copy of valid Company Registration Certificate (TDP);

f. Copy of valid General Import Identification Number (API-U), specifically for distributors or sole distributors;

g. Copy of Deed of Establishment of Company and/or Deed of Amendment that has been approved by the competent authority;

h. Copy of ratification of Legal Entity from the Ministry of Law and Human Rights for Limited Liability Companies; 
i. Specifically for agents or sole agents, make a statement stating that they do not control and store the goods of the agency;

j. Original leaflet/brochure/catalog from the principal for the types of goods and/or services that are authorized;

k. Copy of license or other registration letter from the technical agency that is still valid for certain types of goods in accordance with applicable regulations;

1. Copy of Permanent Business Permit/BKPM Approval Letter if the agreement is made with a Foreign Investment Company (PMA) engaged in the distributor/wholesaler field;

m. Copy of Business License for Foreign Trade Representative Companies (SIUP3A) if the agreement is made with a Representative Office of Foreign Trade Companies.

Based on the conditions mentioned above, it can be seen that the importer is one of the parties who entered into an agreement, specifically a sale and purchase agreement. Therefore, to become an importer must comply with the terms of the agreement in the Civil Code as a buyer and the Minister of Trade Republic of Indonesia Regulation No. 11/MDAG/PER/3/2006 Provisions and Procedures for Issuance of Registration Certificate of Agents or Distributors of Goods and/or Services as distributors.[7]

\subsection{Food Import Objects}

From the definition of food according to the Food Law discussed, it can be concluded that food is anything that is eaten or drunk by humans in order to preserve and maintain the quality and quantity of health. Because of the importance of food to the human body, food needs to be protected by the regulation of food requirements in order to maintain the quality of the food.

\section{a) Food Import Object Requirements}

The imported food objects which are circulated must fulfill certain requirements. Based on Article 1320 the Civil Code governs the agreement, there are objective conditions mentioned on the third and fourth. tThese conditions must be fulfilled by the object of the agreement. Failure to fulfill objective conditions will result in an agreement being made null and void by law. This means that from the beginning it was thought that a contract was never born and there was never an agreement.[6] The objective conditions stipulated in Article 1320 of the Civil Code are:

a. Specific Objects/Subject

b. Permitted/halal causes

According to Article 37 and Article 38 of the Food Law, food imports are permitted on the condition that they must meet the following conditions:

a. Meet the requirements of safety, quality, nutrition, and do not conflict with the religion, beliefs, and culture of the community;

b. As well as meeting the expiration and food quality limits.

\section{b) Prohibition and Restriction of Food Import Objects}

Prohibited and/or restrictive goods are goods that are prohibited and/or restricted from importing or expending into and from customs areas.[8] Prohibitions and restrictions especially in the field of export-import are regulated in Law No. 7 of 2014 concerning Trade Article 50 to Article 54 which regulates the matter of all goods that have a sufficiently long period of time which can cause cancer. Exported or imported, except those prohibited, 
restricted or otherwise determined by law. The government prohibits the import or export of goods for the national interest by reason of:

a. To protect national security or the public interest, including social, cultural, and moral of society;

b. To protect intellectual property rights; and/or

c. To protect the health and safety of humans, animals, fish, plants and the environment.

To find out whether an item can be imported or not, you must look at the special provisions governing the item.

\section{c) Out of date}

Expiration is prohibited by law because it can harm consumers if they consume it. Expiration has the meaning of having passed or the expiry of the time period as specified and if consumed, then the food can endanger the health of those who consume it. Based on the provisions of Article 90 of the Food Law regulates food that is prohibited from being distributed, namely contaminated food. The polluted means in the Food Law in the form of:

a. Food containing toxic, dangerous or dangerous material for human health or life;

b. Contains contaminants that exceed the maximum threshold set; contain materials which are prohibited from being used in Food Production activities or processes;

c. Contains material that is dirty, rotten, rancid, decomposed, or contains vegetable or animal material which is diseased or derived from a carcass;

d. Produced in a way that is prohibited; and

e. Has expired.

\section{d) Expired Food Features}

Meanwhile, the characteristics of food products that have expired or expired can be seen from the form of packaging that has changed, such as:[9]

a. The can is swollen.

b. Food has changed color because it has been moldy.

c. It does not taste like it is promoted on a tin.

d. Cause an unpleasant odor when opened.

e. Product packaging is not the latest packaging but still with the old model packaging.

f. The dusty product packaging is not a guarantee that the product is still suitable or not for consumption.

e) Due to Consuming Expired Foods

Eating expired foods has implications for various parties. These parties are consumers and producers. Consequently for consumers because consumers are those who consume them ; whereas, producers are parties that sell or distribute them. The consequences are:

a. For Consumers. Food poisoning is a disease caused by consuming unhealthy foods. Common symptoms of poisoning include heartburn, nausea, vomiting, diarrhea and sometimes accompanied by redness, cramps and fainting. In addition to health problems, the material losses suffered by consumers are losses that are not directly suffered by consumers but rather losses that can be valued in money and these losses are material. [10]

b. For Manufacturers. Expired foods not only affect consumers but producers are also be affected, namely:[11] 
a) Expropriation of certain items

b) Announcement of the judge's decision

c) Payment of compensation

d) Orders to stop certain activities that cause consumer losses

e) Obligation to withdraw goods from circulation, or

f) Revocation of business license

\subsection{Responsibility of Distributors as Business Executors Against Expired Import Food}

Distributor is a national trading company that acts for and on its own behalf based on agreements that purchase, store, sell and market goods and/or services owned/controlled.

\subsubsection{Distributor Requirements}

The requirements that must be met are based on Article 8 of the Minister of Trade's Regulation No. 11/M-DAG/PER/3/2006, namely:[7]

1) Application for registration as a distributor or sole distributor of goods and/or overseas production services is submitted to the Director of Business Development and Company Registration by enclosing documents:

a. Agreement that has been legalized by the Public Notary and a certificate from the Indonesian Trade Attache or the Official of the Republic of Indonesia Representative Office in the principal country, by showing the original;

b. If the agreement is made by the supplier's principal, the supplier's principal is obliged to show the authority of the producer's principal;

c. Copy of Trading Business License (SIUP);

d. Copy of valid Company Registration Certificate (TDP);

e. Copy of valid General Import Identification Number (API-U), specifically for distributors or sole distributors;

f. Copy of Deed of Establishment of Company and/or Deed of Amendment that has been approved by the competent authority;

g. Copy of ratification of Legal Entity from the Ministry of Law and Human Rights for Limited Liability Companies;

h. Specifically for agents or sole agents, make a statement stating that they do not control and store the goods of the agency;

i. Original leaflet/brochure/catalog from the principal for the types of goods and/or services that are authorized;

j. Copy of license or other registration letter from the technical agency that is still valid for certain types of goods in accordance with applicable regulations;

k. Copy of Permanent Business Permit/BKPM Approval Letter if the agreement is made with a Foreign Investment Company (PMA) engaged in the distributor/wholesaler field;

1. Copy of Business License for Foreign Trade Representative Companies (SIUP3A) if the agreement is made with a Representative Office of Foreign Trade Companies.

\subsubsection{The parties}

Distributor is a national trading company that acts for and on its own behalf based on agreements that purchase, store, sell and market goods and/or services owned/controlled. [7] 


\subsection{Principal dan Distributor}

Principal is an individual or business entity in the form of a legal entity or not a foreign or domestic legal entity that appoints an agent or distributor to sell goods and/or services that are owned/controlled. Whereas a distributor is a national trading company that acts for and on its own behalf based on agreements that purchase, store, sell and market goods and/or services owned/controlled.

Based on the above understanding it can be seen that the principal is the party that sells the goods/services. Meanwhile, the distributor is the party who buys the goods/services from the principal but acts for and on his own behalf based on the agreement. The agreement in question is a distribution agreement.

a. Underlying Agreement

The agreement made by the distributor with the principal is referred to as the distributor agreement. The distributor agreement (Distributorship Agreement) is specifically regulated in the Minister of Trade Regulation No. 11/M-DAG/PER/3/2006 concerning Provisions and Procedures for Issuance of Registration Letters for Agents or Distributors of Goods and/or Services (lex-specialis). Distributors operate on their own behalf, so distributors and Principals have equal contractual relationships and are not an employment relationship. The relationship between the Principal and the Distributor is usually made by a Distributor Agreement.

b. Rights and obligations

Based on Article 20 of the Minister of Trade's Regulation No. 11/M-DAG/PER/3/2006 these rights and obligations include:[7]

1) Agents, sole agents, sub agents, distributors, sole distributors or sub distributors are entitled to education and training to improve skills and after sales service from the principal, as well as regularly obtain information about product developments.

2) If necessary, an agent, sole agent, distributor or sole distributor can employ foreign national experts in the technical field in accordance with applicable regulations.

3) Agents, sole agents, distributors or sole distributors are obliged to protect the interests and confidentiality of principals against the goods and/or services that are authorized in accordance with the agreement.

4) Principals Producers who supply goods that are of sustainable use within a minimum period of 1 (one) year are required to provide spare parts or after-sales service and fulfill guarantees or warranties in accordance with the agreed agreements.

Like agreements in general, Distributor Agreements are subject to the Civil Code (Civil Code), especially Book III on Engagement.

\section{c. Responsible}

The responsibility of the distributor for the principal is limited to expanding marketing, meaning that having a distributor helps the principal to market its products in an area where this is an important factor in increasing the profits of the principal company.

\subsection{Distributors and Consumers}

Distributor is a national trading company that acts for and on its own behalf based on agreements that purchase, store, sell and market goods and/or services owned/controlled. Whereas consumers are consumers who are all users of goods and/or services available in the community, both for themselves, their families, other people and other living things and not 
for trade.[11] Based on the above understanding it can be seen the legal relationship between distributors and consumers, namely as sellers and buyers.

\section{a. Underlying Agreement}

Because the distributor acts with and on his own behalf, and it does not concern the principal, so when the distributor enters into an agreement with the consumer, the consumer cannot sue the principal but only the distributor can be sued by the consumer. This agreement between the distributor and the consumer is referred to as the sale-purchase agreement. Referred to as a sale-purchase agreement because in a sale-purchase agreement regulated in the Civil Code the distributor is referred to as the seller, while the consumer is referred to as a buyer. The sale and purchase agreement consists of two syllables namely sell and buy.

\section{b. Rights and obligations}

[1] Seller Rights

The rights of the seller are:[12]

a. The right to declare null and void, if the buyer does not pay the purchase price, then the seller can demand the cancellation of the purchase of merchandise and home furnishings without giving a warning to the buyer, after the elapsed time has passed for the goods to be sold. (Ps.1518 Civil Code)

b. The seller has the right not to surrender the goods he sells. If the buyer has not paid the price, the seller will not be allowed to delay the payment. (Ps.1478 Civil Code) This is a rebuttal called "exceptio non adempleti contractus" is a rebuttal stating that he (the debtor) did not carry out the agreement as it was precisely precisely because the creditor himself did not carry out the agreement as it should.[13]

c. The seller is given the power to buy back goods that have been sold issued from a promise, where the seller is given the right to take back the goods he sold, by returning the original purchase price, accompanied by compensation. (Ps.1519 Civil Code) all costs according to the law that have been incurred to carry out the purchase and delivery, as well as the necessary costs required for corrections, and costs that cause the goods being sold increase in price, this additional amount. (Ps.1532 Civil Code)

[2] Obligations of the Seller

Within the Article 1474 of the Civil Code, there are 2 (two) main obligations for the seller, namely:

a. The seller give up ownership rights on the goods being traded. Obligation to surrender property rights includes all acts that are required by law to transfer ownership of the goods sold and purchased from the seller to the buyer. In the delivery of goods the provisions that must be considered by the seller, include:

b. The delivery of the item is carried out at the place where the goods were at the time the sale occurred, except in other agreements (Article 1477 of the Civil Code).

c. The goods delivered must be intact as stated in the agreement or at the time of sale (Article 1481 in conjunction with Article 1483 of the Civil Code).

d. The seller is obliged to surrender everything that becomes equipment to use the goods that he has sold (Article 1482 of the Civil Code).

e. The seller is not required to surrender the goods before the buyer pays the price (Article 1478 of the Civil Code). 
f. The seller is obliged to guarantee the buyer to be able to have the goods safely and securely, and be responsible for hidden defects that can be used as a reason for canceling the purchase (Articles 1491, 1504, 1506, 1508, 1509 and 1510 Civil Code), but the seller is not obliged to bear visible defects by the buyer (vide Article 1505 of the Civil Code).

g. The seller is obliged to bear the loss suffered by the buyer if it turns out that the goods that have been traded must be confiscated or must be taken from the buyer due to a dispute, which is caused by no prior notification when entering into a sale and purchase agreement (Articles 1492, 1495, 1496, 1497, 1499 Civil Code).

h. The seller is obliged to be responsible for anything that is a direct result of the maker so that it harms the buyer, although in the agreement it is determined that the seller does not bear all the risks in the sale and purchase (Article 1494 of the Civil Code).

i. The seller is obliged to use the cost of delivering goods, meaning that in the agreement it is determined that the delivery is carried out in the buyer's warehouse, then the transportation costs from the seller's place to the buyer's warehouse are borne by the seller, while the cost of taking from the buyer's warehouse to the buyer's place is borne by the buyer (Article 1476 of the Civil Code ).

j. The seller is obliged to return the price of goods and costs according to the applicable laws and regulations, the buyer has the right to cancel or cancel the purchase (Article 1488 of the Civil Code) on condition that the claim must be made no later than 1 year after the delivery of the goods (Article 1489 of the Civil Code).

k. The seller is obliged to bear the loss suffered by the buyer if it turns out that the goods that have been traded must be confiscated or must be taken from the buyer due to a dispute, which is caused by no prior notification when entering into a sale and purchase agreement (Articles 1492, 1495, 1496, 1497, 1499 Civil Code).

1. The seller is obliged to be responsible for anything that is a direct result of the maker so that it harms the buyer, although in the agreement it is determined that the seller does not bear all the risks in the sale and purchase (Article 1494 of the Civil Code).

m. The seller is obliged to use the cost of delivering goods, meaning that in the agreement it is determined that the delivery is carried out in the buyer's warehouse, then the transportation costs from the seller's place to the buyer's warehouse are borne by the seller, while the cost of taking from the buyer's warehouse to the buyer's place is borne by the buyer (Article 1476 of the Civil Code ).

n. The seller is obliged to return the price of goods and costs according to the applicable laws and regulations, the buyer has the right to cancel or cancel the purchase (Article 1488 of the Civil Code) on condition that the claim must be made no later than 1 year after the delivery of the goods (Article 1489 of the Civil Code).

o. The seller bears the pleasure of the goods and bears the hidden damages. The obligation to bear pleasure is a consequence of the guarantee given by the seller to the buyer that the goods sold and levered are really his own that is free from any party.[14]

[3] Buyer's rights

If Article 1495 of the Civil Code is not implemented, the buyer will have the right to claim back from the seller:

a. To refund for damages

b. To receive goods purchased from the seller. 
c. To get a guarantee from the seller regarding the enjoyment and absence of hidden damage.

[4] Obligations of the Buyer

Based on Article 1513 of the Civil Code the main obligation of the buyer is to pay the purchase price at the time and place as determined according to the agreement.

\section{Responsible}

In the case of a distributor as a business actor who does not fulfill his obligations, he is subject to sanctions. Based on the Food Law, the responsibility of business actors, namely administrative sanctions, are in the form of:
a. Fine;
b. Temporary cessation of activities, production and/or distribution.
c. Withdrawal of food from circulation by producers;
d. Compensation; and/or
e. Revocation of permission.

\section{Conclusion}

Based on the description that has been stated in previous chapters, conclusions can be drawn including the following:

1. The regulation regarding imported food is regulated under Law No. 18 of 2012 on Food, hereinafter referred to as the Food Law. According to Article 37 and Article 38 of the Food Law, imported foods are allowed for distribution only if they meet the requirements of safety, quality, and nutrition. do not have conflict with the religion, beliefs and culture, and meet the expiration and food quality limits. Furthermore, the laws also regulate any food which are prohibited for distribution under Article 90, which is simply call contaminated food. Contaminated foods referred to Food Law is any food containing toxic, dangerous, or material that can endanger human health or life; contains contamination that exceeds the maximum limit set; contains materials which are prohibited from being used in Food Production activities or processes; contain material that is dirty, rotten, rancid, decomposed, or contains vegetable or animal material which is diseased or derived from a carcass; produced in a way that is prohibited; and has expired. Further arrangements with expiration requirements are regulated in Article 90 of the Food Law which regulates tainted food because expiration is one form of contamination and is prohibited by the Food Law.

2. Distributors as importers of foods are responsible for their actions in distributing expired imported food as stipulated in Article 94 of the Food Law, and they will be charged in the form of Fines; Temporary cessation of activities, production and/or distribution; Withdrawal of food from circulation by producers; Compensation; and/or Revocation of license. 


\section{References}

[1] Law No. 18 of 2012 concerning Food. .

[2] Z. Asyadie, Hukum Bisnis. Jakarta: Raja Grafindo Persada, 2005.

[3] S. Hura, D. L., Njatrijani, R., and Mahmudah, "Perlindungan Hukum Bagi Konsumen terhadap Makanan Olahan Mengandung Bahan Berbahaya di Jawa Tengah," Diponegoro Law J., vol. 5, no. 4, pp. 1-18, 2016.

[4] S. Soekanto, S., \& Mamudji, Penelitian hukum normatif: Suatu tinjauan singkat. Jakarta: Raja Grafindo Persada, 2001.

[5] Law No. 7 of 2014 concerning Trade. .

[6] Komariah, Hukum Perdata. Malang: Universitas Muhammadiyah Malang, 2002.

[7] Regulation of the Ministry of Trade of the Republic of Indonesia No. 11/MDAG/PER/3/2006 concerning Provisions and Procedures for Issuance of Registration Certificate of Agents or Distributors of Goods and/or Services. .

[8] Regulation of the Minister of Finance Number 161/Pmk.04/2007 concerning Supervision of Import or Export of Prohibited and/or Restricted Goods. .

[9] mediaindo.co.id, "No Title," 24 Januari 2018. .

[10] Y. Salim, P., and Salim, Kamus Bahasa Indonesia Kontemporer. Jakarta: English Press, 2002.

[11] Law No. 8 of 1999 concerning Consumer Protection. .

[12] Civil Code (KUH Perdata). .

[13] R. Syahrina, Seluk Beluk dan Asas-Asas Hukum Perdata. Bandung: Alumni, 2006.

[14] Subekti, Aneka Perjanjian. Bandung: Alumni, 1985. 